Farne, S. (1959). J. gen. Microbiol. 20, 246-251.

\title{
Iron as a Growth Requirement for Pathogenic Leptospira
}

\author{
By S. FAINE* \\ Microbiology Department, Otago University Medical School, Dunedin, \\ New Zealand
}

SUMMARY: Virulent and avirulent strains of Leptospira icterohaemorrhagiae did not grow from inocula of fewer than $10^{2}$ organisms/ml. in Korthof medium, but did grow when $\mathrm{FeCl}_{3}$ or preparations containing iron porphyrins were added. With added $\mathrm{FeCl}_{3}$ or haematin growth was somewhat slower than when the iron porphyrin-containing preparations were added.

Many authorities have recommended that the serum essential in culture media for pathogenic leptospires should contain small quantities of haemolysed erythrocytes, or that a solution of laked erythrocytes should be added as a 'source of haemoglobin' (Alston \& Broom, 1958; Wolff, 1954). There has been no agreement about the need for haemoglobin nor suggestions about its possible functions. This report describes experiments made with Korthof medium which did not support growth of Leptospira but did so when $\mathrm{FeCl}_{3}$, haematin or preparations containing iron-porphyrin compounds were added.

\section{METHODS}

Organisms. The strains used were Leptospira icterohaemorrhagiae (Jackson) avirulent for guinea-pigs, and $L$. icterohaemorrhagiae (Field), virulent and in its 5th laboratory subculture since guinea-pig passage. They were obtained in 1953 from Dr J. C. Broom (Leptospira Reference Laboratory, Wellcome Laboratories of Tropical Medicine, London) and maintained in modified Korthof medium. Incubation was at $30^{\circ}$.

Counting method. A direct counting method (Faine, 1957) was used.

Culture medium. Broom's modification (Alston \& Broom, 1958) of Korthof's medium (Korthof, 1932) was used but with the substitution of Neopeptone (Difco) for the Witte peptone recommended. All other ingredients were 'pure' or of analytical grade. The batch of medium used in these studies, designated K11, was prepared to contain $10 \%(\mathrm{v} / \mathrm{v})$ pooled rabbit serum obtained by heart puncture, care being taken to avoid haemolysis. The medium was sterilized by filtration through a Seitz E.K. filter-pad; it contained $40 \mu \mathrm{g} . \mathrm{Fe} / 100 \mathrm{ml}$. This concentration of $\mathrm{Fe}$ may be compared with that in a sample of a complete medium with added 'Hb solution' (see below) adequate for growth and which contained $c .190 \mu \mathrm{g}$. iron $/ 100 \mathrm{ml}$.

Sources of iron and porphyrins. Solutions containing haemoglobin ('haemoglobin solution' $=\mathrm{Hb}$ solution in the sequel) were prepared by repeatedly freezing and thawing washed packed rabbit erythrocytes, and were sterilized

\footnotetext{
* Present address : Department of Bacteriology, University of Sydney, Sydney, Australia.
} 
by Seitz filtration. The haemoglobin content of this material was measured photometrically and dilutions were prepared from a stock standard solution. Solutions containing derivatives of haemoglobin were prepared from $\mathbf{H b}$ solution as follows: containing carboxyhaemoglobin (COHb) by bubbling coal-gas through; containing methaemoglobin (MetHb) by adding $0 \cdot 2 \%(w / v)$ potassium ferricyanide; containing 'boiled $\mathrm{Hb}$ ' by boiling for $30 \mathrm{~min}$.; containing ' heated $\mathrm{Hb}$ ' by heating at $56^{\circ}$ for $30 \mathrm{~min}$. Haematin was prepared by adding $\mathrm{NaOH}$ to crystalline ox haemin. $\mathrm{FeCl}_{3}$ was diluted from 'Analar' $60 \%(\mathrm{w} / \mathrm{v})$ solution. Water distilled twice from glass was used to rinse glassware and for dilutions.

\section{RESULTS}

\section{The need for iron or iron porphyrin compounds}

It was found that the leptospires used would not grow well in medium $\mathrm{K} 11$, but that this supported luxuriant growth when a little $\mathrm{Hb}$ solution was added. In an experiment to find substitutes for the $\mathrm{Hb}$ solution, $16 \mathrm{ml}$. of medium $\mathrm{K} 11$ were inoculated with $0.5 \mathrm{ml}$. of a 3-day culture of Leptospira icterohaemorrhagiae (Jackson); the final concentration was $10^{6}$ organisms $/ \mathrm{ml}$.

Table 1. Growth-promoting effect of $\mathrm{FeCl}_{3}$ and material containing haemoglobin and certain derivatives

The medium K11 (iron and porphyrin deficient) was inoculated with $10^{\circ}$ leptospires/ml.

Supplements were added to $c \cdot 10^{-4} \mathrm{M}$ final concentration, in duplicate series. The numbers of leptospires given are average of duplicates.

\begin{tabular}{|c|c|c|}
\hline \multicolumn{3}{|c|}{ Period of incubation (days) } \\
\hline 4 & 7 & 18 \\
\hline \multicolumn{3}{|c|}{ Leptospires (millions)/ml. } \\
\hline 2 & 7 & $\mathbf{1}$ \\
\hline 110 & 309 & 167 \\
\hline 99 & 295 & - \\
\hline 145 & 324 & 一 \\
\hline 130 & - & - \\
\hline 34 & 232 & 280 \\
\hline 82 & 164 & - \\
\hline 44 & 286 & 125 \\
\hline
\end{tabular}

The inoculum was contained in $1 / 30$ the volume of medium to be inoculated. The inoculated medium was distributed in duplicate $1 \mathrm{ml}$. volumes. To each of two control tubes was added $0.01 \mathrm{ml} . \mathrm{H}_{2} \mathrm{O}$. To each of other pairs was added $0.01 \mathrm{ml}$. of a $c .0 .01 \mathrm{~m}$ solution containing one of the following: $\mathrm{Hb}$, boiled $\mathrm{Hb}$, heated $\mathrm{Hb}, \mathrm{COHb}, \mathrm{MetHb}$, haematin or $\mathrm{FeCl}_{3}$. The organisms were counted in each tube after incubation for 4, 7 and 18 days at $30^{\circ}$ (Table 1 ). Growth was slower with added haematin or $\mathrm{FeCl}_{3}$ than with the other supplements. Similar results were obtained with two virulent strains of $L$. icterohaemorrhagiae. Growth in medium $\mathrm{K} 11$ was not enhanced by heating it at $56^{\circ}$ for $30 \mathrm{~min}$., nor by adding 1,10 or $100 \mu \mathrm{g}$. cyanocobalamin $/ \mathrm{ml}$, or $10^{7}$ boiled washed leptospires $/ \mathrm{ml}$. 


\section{Optimum concentration of added iron or other supplement}

The optimum concentration of $\mathrm{Hb}$ solution or $\mathrm{Fe}$ to promote growth was found by adding serially diluted solutions to inoculated K11 medium. Duplicate tenfold serial dilutions of $\mathrm{Hb}$ solution and of $\mathrm{FeCl}_{3}$ containing the equivalent of $10^{-2} \mathrm{M}-\mathrm{Fe}$ were made in sterile double glass-distilled water. To tubes containing $0.98 \mathrm{ml}$. of medium $\mathrm{K} 11$ were added $0.01 \mathrm{ml}$. of the appropriate dilution of $\mathrm{Hb}$ solution or $\mathrm{FeCl}_{3}$ and $0.01 \mathrm{ml}$. of a $1 / 10$ dilution of a 4-day culture of Leptospira icterohaemorrhagiae. This resulted in a range of Fe concentrations from $10^{-4}$ to $10^{-8} \mathrm{M}$ (as $\mathrm{Hb}$ solution or $\mathrm{FeCl}_{3}$ ). Each tube contained in $1.0 \mathrm{ml}$. of medium $10^{4}$ leptospires and $10^{-3} \mathrm{ml}$. of medium carried over from the inoculating culture. Control tubes contained supplements of double glass-distilled water alone. The organisms were counted at intervals (Table 2), but not all tubes were counted at the same time. The optimum supplement concentration was equivalent to $c .10^{-5} \mathrm{M}-\mathrm{Fe}$ as haemoglobin in the $\mathrm{Hb}$ solution or as $\mathrm{FeCl}_{3}$. Growth was faster with added $\mathrm{Hb}$ solution than with added $\mathrm{FeCl}_{3}$ at equivalent $\mathrm{Fe}$ concentrations. There was a threshold concentration of added iron which was just above the concentration in unsupplemented medium.

\section{Effect of size of inoculum}

It has frequently been stated that a large inoculum of $1 / 6-1 / 10$ volume should be used in routine subculture of leptospires (Wolff, 1954; Alston \& Broom, 1958; Rimpau, 1950; Wiesmann, 1952); this would be equivalent to c. $10^{7}$ organisms $/ \mathrm{ml}$. Inocula of $c .100$ washed or unwashed organisms $/ \mathrm{ml}$. grew typically and satisfactorily in Korthof medium. The function of a large inoculum would seem to be to supply iron or some iron-porphyrin contained in the transferred leptospires or medium. Half a washed suspension of organisms from a 5-day culture in adequate medium was serially 10-fold diluted in duplicate $1 \mathrm{ml}$. volumes of medium $\mathrm{K} 11$. The other half was similarly diluted in medium $\mathrm{K} 11$ containing the equivalent of $10^{-5} \mathrm{M}$ haemoglobin as $\mathrm{Hb}$ solution. Final concentrations of inoculum were $10^{8}$ to $10^{2}$ organisms $/ \mathrm{ml}$. Growth up to $c .10^{8}$ leptospires $/ \mathrm{ml}$. occurred in 2-13 days in all media with added $\mathrm{Hb}$ solution. From one to four generations occurred in $c .5$ days in medium K11 without added $\mathrm{Hb}$ solution and inoculated with $10^{8}$ or $10^{7}$ organisms $/ \mathrm{ml}$., but there was no growth in tubes inoculated with $10^{6}$ organisms or less $/ \mathrm{ml}$, , within 20 days. In a similar experiment boiled organisms to $5 \times 10^{7} / \mathrm{ml}$. added to each tube of K11 medium prolonged survival of inocula of $10^{6}$ organisms $/ \mathrm{ml}$. as compared with the controls, but did not promote growth nor alter the results in other tubes.

\section{DISCUSSION}

There has hitherto been little or no evidence that haemoglobin, a constituent of many recipes for culture media for Leptospira, is an essential nutrient requirement for these organisms; nor has there been any indication of its possible functions. Unless special precautions are taken, at least traces of 


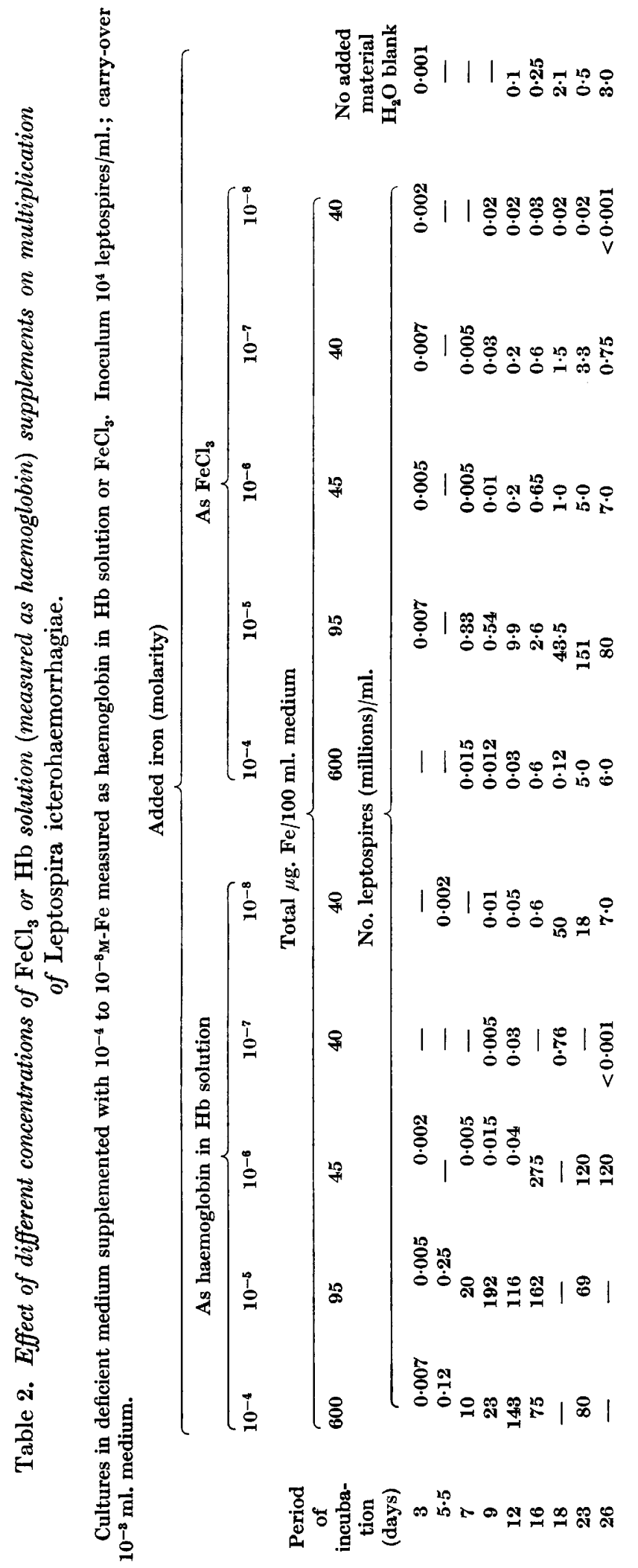


haemoglobin are probably present in the serum which is generally used in all media for Leptospira. The original Korthof medium (Korthof, 1932) did not recommend the addition of laked erythrocytes, but Broom's modification does (Alston \& Broom, 1958). Babudieri (1943) found that adding laked erythrocytes made no difference to the ability of Leptospira to survive for long periods in culture media. Czekalowski, McLeod \& Rodican (1953) were unable to show catalase or unequivocal oxidase activity in their organisms and later suggested that media containing laked erythrocytes were better than others because this material supplied catalase (Czekalowski, McLeod \& Rodican 1954). Fulton \& Spooner (1956) showed the spectrum of cytochrome $c$, and Faine (1958) demonstrated oxidase but not catalase activity, in Leptospira icterohaemorrhagiae (Jackson); the 'Field' strain and many other serotypes of Leptospira contained oxidases as well as catalase. Haemoglobin may be a source of $\mathrm{Fe}$ and porphyrin for the building of these enzymes. The Leptospira used in the present experiments grew very slowly and to a limited extent unless $\mathrm{Fe}$, or material containing iron porphyrins, were added. The faster growth rate with $\mathrm{Hb}$ solution and some derivatives of it than with haematin or $\mathrm{Fe}$ suggested that Leptospira may synthesize more slowly from medium constituents $+\mathrm{Fe}$ those cellular components, presumably Fe porphyrin enzymes, for which the iron porphyrin compounds from laked erythrocytes are more effective precursors. Haematin was a constituent of the defined and partially defined media proposed by Savino \& Rennella (1943). Tap water, recommended for use in many commonly used media, such as the original medium of Vervoort-Schüffner (see van Thiel, 1948) would provide significant amounts of $\mathrm{Fe}$. On the other hand, Fe might be removed by chelation with phosphates during the preparation of these media. Traces of Fe might be introduced by filtration through filter pads (Hunter, 1943). The optimum Fe supplement of $10^{-5} \mathrm{M}$ corresponds approximately to the concentration of haemoglobin in modified Korthof medium (Alston \& Broom, 1958) supplemented with $\mathrm{Hb}$ solution as used here.

A heavy inoculum of culture equivalent to $1 / 6-1 / 10$ of the volume of medium to be inoculated has been recommended and used by many workers (Alston \& Broom, 1958; Wolff, 1954). Enough Leptospira organisms might thus be transferred for growth to become visible after only 4-5 divisions, which is the degree of growth obtained in medium K11 inoculated with $10^{7}$ or more washed organisms $/ \mathrm{ml}$. Personal experience shows that c. 1-5 $\times 10^{7}$ leptospires $/ \mathrm{ml}$. can be seen with the naked eye in tubes or bottles of 10-20 mm. internal diameter. Thus iron or iron porphyrin deficiency may not be important when media are very heavily inoculated. Conversely, large inocula are not necessary for growth in media made adequate by addition of iron or iron porphyrin-containing material because $10^{2}$ washed leptospires $/ \mathrm{ml}$. grew to usual numbers, $c .10^{8} / \mathrm{ml}$., in medium $\mathrm{K} 11$ supplemented with $\mathrm{Hb}$ solution.

This work was assisted by a grant from the New Zealand Medical Research Council. I am greatly indebted to Dr Frank H. Sims, Auckland Public Hospital, for arranging iron estimations, to Dr J. B. Howie, Pathology Department, Otago University Medical School for $\mathrm{Hb}$ estimations and to Miss Janet Oldham for technical assistance. 


\section{REFERENCES}

Alston, J. M. \& Broom, J. C. (1958). Leptospirosis in Man and Animals. Edinburgh: E. and S. Livingstone Ltd.

Babudieri, B. (1943). Das Úberleben von Leptospiren auf Serum- und Blutnährböden. Zbl. Bakt. (1 Abt. Orig.), 150, 243.

Czeralowski, J. W., McLeod, J. W. \& Rodican, J. (1953). The growth and respiration of Leptospira in solid or semi-solid media with special reference to Dinger's phenomenon. Brit. J. exp. Path. 34, 588.

Czekalowski, J. W., Mcleod, J. W. \& Rodican, J. (1954). Observations on the nutrition of Leptospira based on the development of Dinger's phenomenon. J. gen. Microbiol. $10,199$.

FaINe, S. (1957). Virulence in leptospira. I. Reactions of guinea-pigs to experimental infection with Leptospira icterohaemorrhagiae. Brit. J. exp. Path. 38, 1.

FaINE, S. (1958). Respiratory enzyme activity, and the need for haemoglobin in cultures of pathogenic leptospira. Proc. Univ. Otago Med. Sch. 36, 27.

Fulton, J. D. \& Spooner, D. F. (1956). The metabolism of Leptospira icterohaemorrhagiae in vitro. Exp. Parasit. 5, 154.

HunTer, G. J. E. (1943). Growth-promoting substances from bacteriological filter pads. Biochem. J. 37, 577.

Kontноғ, G. (1932). Experimentelles Schlammfieber beim Menschen. Zbl. Bakt. (1. Abt. Orig.), 125, 429.

Rimpau, W. (1950). Die Leptospirose. München: Urban and Schwarzenberg.

Savino, E. \& Rennella, E. (1943). El cultivo de la Leptospira icterohaemorrhagiae Inada e Ido, 1915. IV. Cultivo en medio sintético y semisintético. Rev. Inst. bact. Malbran. 11, 322. (Abstract by Broom, J. C. (1944). Bull. Hyg. 19, 484.)

Van Thiel, P. H. (1948). The Leptospiroses. Leiden: Universitaire Pers Leiden.

Wiesmann, E. (1952). In Leptospirosen, by Gsell, O. and Wiesmann, E. Bern: H. Huber.

WoLFF, J. W. (1954). The Laboratory Diagnosis of Leptospirosis. Springfield, Ohio: C. C. Thomas. 